\title{
Is the grass greener on the other side? A longitudinal study of the impact of employer change and occupational change on job satisfaction
}

Article

Accepted Version

Creative Commons: Attribution-Noncommercial-No Derivative Works 4.0

Zou, M., Zhou, Y., Williams, M. and Tabvuma, V. (2017) Is the grass greener on the other side? A longitudinal study of the impact of employer change and occupational change on job satisfaction. Journal of Vocational Behavior, 99. pp. 66-78. ISSN 0001-8791 doi: https://doi.org/10.1016/j.jvb.2016.11.005 Available at https://centaur.reading.ac.uk/71966/

It is advisable to refer to the publisher's version if you intend to cite from the work. See Guidance on citing.

To link to this article DOI: http://dx.doi.org/10.1016/j.jvb.2016.11.005

Publisher: Elsevier

All outputs in CentAUR are protected by Intellectual Property Rights law, including copyright law. Copyright and IPR is retained by the creators or other copyright holders. Terms and conditions for use of this material are defined in the End User Agreement. 


\section{CentAUR}

Central Archive at the University of Reading

Reading's research outputs online 


\section{Is the Grass Greener on the Other Side? A Longitudinal Study of the Impact of Employer Change and Occupational Change on Job Satisfaction}

Ying Zhou, Min Zou, Mark Williams, Vurain Tabvuma

Keywords: adaptation; employer change; job satisfaction; occupational change

1. Introduction

An extensive body of research shows that individuals experience a honeymoon-hangover effect following job change (Boswell and Bourdreau, 2005; Boswell, Shipp, Payne and Culbertson, 2009; Chadi and Hetschko, 2014; Georgellis and Tabvuma, 2010; Georgellis and Yusuf, 2016). The pattern is characterised by a significant increase in the reported level of job satisfaction when individuals enter the new job ('honeymoon') and its subsequent decline back to the baseline over time ('hangover'). Research shows that the honeymoon effect often results from organizations' tendency to portray their most favourable characteristics to new recruits during the hiring and initial socialisation processes (Ashforth, 2001; Van Maanen, 1975; Tabvuma, Georgellis and Lange, 2015) combined with individuals' tendency to rationalise the decisions which they have already made (Lawler, Kuleck, Rhode and Sorensen, 1975; Vroom and Deci, 1971). The hangover effect can be accounted for by socialization theory (Chatman, 1991; Louis, 1980) or set point theory (Headey and Wearing, 1989), both of which suggest that individuals adapt to changes over time as they gain increased information about and exposure to the new environment. 
The literature on the honeymoon-hangover effect has generally treated job changers as a relatively homogenous category of employees. However, job change involves two distinct types of processes: 1) moving to a different employer while continuing in a similar type of job (employer changes within occupations); and 2) moving to a different employer while also moving to a different type of job (employer changes across occupations). Making this distinction is important because the two job-related changes differ in many ways which can lead to fundamentally different implications for consequent well-being and workplace behaviour.

Occupational change is a significant life event because substantial research has shown that occupation represents an important indicator of individuals' socioeconomic status and plays a critical role in shaping job tasks, skill set, economic rewards, subculture, and social identity (Goldthorpe, 2007, Grusky and Sorensen, 1998; Kalleberg and Griffin, 1978; Rose, 2003; Weeden, 2002; Weeden and Grusky, 2012). A change of occupation can result in an erosion of occupation-specific human capital due to change in job tasks and associated skill requirements. The switch can also lead to alterations to one's professional networks and social identity. Changing employers within occupations, on the other hand, mainly involves changes in the external workplace environment without significant modifications to job content. Individuals who change employers within occupations are usually able to continue to apply their job-specific skills and knowledge in their daily work, while occupational changers can confront the significant challenges of starting a new career. These differences imply that individuals' reactions to the new job are likely to differ depending on the type of career transition that they have made. Knowledge of the consequences of different types of job change will help individuals plan their career and employers to understand employees' reactions to their new job which has important implications for work motivation, behaviour and retention (Boswell and Bourdreau, 2005; Boswell et al., 2009). 
To our knowledge, no empirical study has utilised large-scale national longitudinal data to examine the long-term differences in employee experience of these two types of job change. This article aims to bridge this gap by comparing the job satisfaction trajectories of those who change employers within occupations to those who change both employers and occupations. We draw on the data from the British Household Panel Survey to assess the prevalence of the two types of job change in the British labour market during the period 1991-2008 and examine the extent to which there are similarities and differences in overall, intrinsic, and extrinsic job satisfaction between the two groups over time.

\section{Theoretical framework}

\subsection{Employer change, occupational change and job satisfaction}

Research on the impact of job change on job satisfaction has identified systematic patterns to how job satisfaction evolves with respect to the temporal proximity of making the change (Boswell and Bourdreau, 2005; Boswell et al., 2009; Chadi and Hetschko, 2014). The pattern is characterised by a dip in job satisfaction preceding separation and a sharp rise in job satisfaction upon entry into the new job (the honeymoon effect). Over time as individuals adapt to the new environment job satisfaction gradually returns to the baseline level (the hangover effect).

There are several reasons for the observed 'honeymoon' and 'hangover' effects. For instance, the honeymoon effect can be influenced by the overly positive message conveyed by employers during the recruitment process (Ashforth, 2001, Ilgen, 1971; Ward and Athos, 1972). Moreover, individuals are also predisposed to view their new job in a positive light (Fichman and Levinthal, 1991; Leblibici and Salancik, 1982), as memory of the negative aspects of the previous job (which are likely to have motivated separation) often serve as a benchmark against which the new job is evaluated (Boswell and Boudreau, 2005). This 
contrast can result in initial elevated positive reporting of job satisfaction. As time passes, however, individuals acquire more information about the new organization and the less favourable job features become more evident, which lead to a gradual decline of job satisfaction to its baseline level (Boswell and Bourdreau, 2005; Chatman, 1991; Louis, 1980). In summary, the emotional journey through the job change process reflects raised expectations about the new job and a subsequent disenchantment as people return to mundane daily activities.

In contrast to the rich discussions about the causes of honeymoon-hangover effects, the issue of how these effects differ between different types of job change has received little attention. An important distinction concerns whether the job change involves only a change of employer or a change of both employer and occupation. The distinction is important because the former is associated with changing the environment in which work activities are carried out whereas the latter is related to switching both work environment and the nature of job tasks. There is a vast body of research showing that job nature is a significant determinant of both extrinsic and intrinsic job rewards (e.g., Goldthrope, 2007; Mouw and Kalleberg, 2010; Rose, 2003; Weeden and Grusky, 2005; Williams, 2013). A change of both employer and occupation therefore represents a more radical transition, which might have different implications for job satisfaction compared to employer changes within occupations.

Occupation switching can influence job satisfaction for a number of reasons. First, job characteristics theory points to the importance of core job characteristics (skill variety, task identity, task significance, autonomy, and feedback from the job) for shaping employees' work motivation and job satisfaction (Hackman and Oldham, 1980). Occupations differ substantially in the nature of job tasks and associated skill requirements (Gallie, Felstead and Green, 2012; Goldthorpe, 2007; Mouw and Kalleberg, 2010). Occupational change can lead to a sharp disruption in the nature of the job, and hence experienced core job characteristics. 
Individuals' psychological reaction to occupational change is likely to be influenced by the perceived differences between the previous and the new job in terms of central task characteristics.

Second, recent labour economics research shows that human capital is to a significant extent occupation-specific (Hagedorn et al., 2005; Kambourov and Manovskills, 2009; Kwon and Milgrom, 2004; Zangelidis, 2008). Human capital refers to the skills and knowledge, acquired from education and training, that affect individuals' labour productivity (Becker 1993; Lemieux 2006). A rich body of empirical research has shown that occupation-specific human capital contributes significantly to wages, one of the fundamental determinants of job satisfaction. Kambourov and Manovskills (2009) find that controlling for individual and workplace characteristics, five years of occupational tenure is associated with a $12 \%$ wage increase. Once occupational experience is taken into account, employer and industry tenure have little net effect on pay (Kambourov and Manovskills, 2009; Kwon and Milgrom, 2004). When individuals switch occupations, they often experience a 'relative devaluation' of their occupation-specific human capital because the skills required to perform the new job are likely to differ from those required by the previous job. This skill mismatch has significantly negative implications for wages (Parrado et al., 2007; Pavan, 2005). In addition to the potential negative impact from decreased wages, being equipped with inappropriate occupation-specific human capital can also lead to feelings of frustration through skill mismatch (Green, 2013).

Third, social stratification theory suggests that occupation is a key indicator of an individual's socioeconomic position (Davis and Moore, 1945; Goldthorpe, 2007; Weeden, 2002). Members of the same occupation often share relatively homogenous job tasks, subculture, and social identity (Grusky and Sorensen, 1998; Weeden and Grusky, 2005). Research in the 1960s and 1970s explored the link between job satisfaction and occupational 
prestige (Blauner,1960; Kahn, 1972; Jencks, 1972) and recent empirical studies have focused on more explicit occupation-level mechanisms (such as occupational closure practices) that produce the observed inequality in job rewards (Weeden, 2002; Weeden and Grusky, 2005). This perspective implies that besides the loss of valued job-specific skills and experience, switching occupations can also disrupt individuals' occupational networks and social identity, which is likely to have a negative impact on psychological adjustment.

On the other hand, there is a more optimistic perspective which argues occupational change can reflect natural career progression (Stewart, Prandy and Blackburn, 1980). Challenging Slocum's (1966) definition of an occupational career as 'an orderly sequence of development extending over a period of years and involving progressively more responsible roles within an occupation', Stewart et al. (1980) argue that career development often spans across occupations, using the example of professional engineers who move from technical positions to managerial positions after gaining sufficient experience in the industry. A similar notion of 'bridging occupations' was suggested by Broom and Smith (1963) to describe individuals moving between occupations as a means of advancing their career.

Even when occupational change does not involve upward mobility, it can still reflect a functional process of career adjustment (Longhi and Brynin, 2010). Person-Environment Fit theory suggests that employees experience higher levels of job satisfaction when their individual-specific needs are met by the intrinsic and extrinsic rewards provided by the job (Edwards, 1991; Lauver and Kristof-Brown, 2001; Kristof-Brown and Guay, 2011). When individuals have made unsatisfying initial career decisions, searching for alternative opportunities that better suit their innate abilities and personality dispositions may lead to higher levels of job satisfaction compared to long-term entrapment in occupations that poorly match their preferences. Drawing on the data from the British Household Panel Survey, Longhi and Bryin (2010) find support for the career adjustment hypothesis by showing that 
occupational change yields positive returns in terms of both wages and job satisfaction. Similar findings are reported by Breeden (1993) based on a sample of 436 university students who participated in a vocational counselling clinic. He finds that individuals who have changed occupations reported significantly higher levels of job satisfaction than non-changers two years after the initial interview. These studies highlight the benefit of switching occupation as a means of achieving improved person-job fit.

\subsection{Job satisfaction and the job change process: Hypotheses}

The job change process consists of three distinct phases: the separation process, the reemployment process, and the adjustment process. Work attitudes tend to systematically vary around these distinct phases (Boswell and Boudreau, 2005; Boswell et al., 2009; Chadi and Hetschko, 2014; Clark, Diener, Georgellis and Lucas, 2008). For instance, turnover research shows that low levels of job satisfaction predicts one's withdrawal from the current job (Clark, Georgellis and Sanfey, 2012; Lévy-Garboua, Montmarquette, and Simonnet, 2007). This may affect both within and across-occupational employer change as dissatisfaction with the current job and/or occupation can all trigger the process of quitting a job and motivate one to search for alternative opportunities. Although much less research has explicitly examined the occupational dimension of changing jobs, given the underlying theory applying to both our first hypothesis is:

Hypothesis 1: Lower levels of job satisfaction precede turnover and the pattern is similar for both employer changes within and across occupations.

The job change literature has also identified a common pattern of an initial rise in the level of job satisfaction following one's entry into the new job, the honeymoon period (Boswell 
and Boudreau, 2005; Boswell et al., 2009; Chadi and Hetschko, 2014). Boswell and Boudreau (2005) argue that this pattern reflects the joint influence of several factors such as employers' overly positive signalling which raises individual expectations of the new job (Van Maanen, 1975; Ashforth, 2001), employees’ post-decision dissonance reduction processes (Lawler et al, 1975; Vroom and Deci, 1971), and individuals' initial psychological forces that shield them from negative thoughts of the new job (Fichman and Levinthal, 1991). As these processes are likely to affect both employer change and occupational change, we do not expect significant differences between the two groups with respect to the initial surge of job satisfaction upon turnover. Our second hypothesis is:

Hypothesis 2: Individuals experience an initial significant increase in job satisfaction when they enter the new job and the pattern is similar for both employer changes within and across occupations.

The adjustment phase following the honeymoon tends to be characterised by a steady fall in job satisfaction back to its former levels over time (Boswell and Bourdreau, 2005; Boswell et al., 2009, Meglino and DeNisi's, 1987). This can be accounted for by socialization theory which suggests that individuals gradually adapt to their new job as they develop greater and more realistic understanding of the values, processes, and practices in the new employing organization (Chatman, 1991; Louis, 1980). With increased tenure at the new workplace, the initial novelty and excitement wears off and job satisfaction returns to its pre-transition levels.

Another perspective from subjective well-being research suggests that individuals are predisposed to different levels of baseline well-being which only change temporarily in the face of external events (Brickman and Campbell, 1971; Brickman et al., 1978; Costa and 
McCrae, 1980; Diener and Diener, 1996; Headey and Wearing, 1989; Lykken and Tellegen, 1996; Vroom and Deci, 1971). Set point theory argues that individuals have 'set points' of well-being, largely determined by genetics and stable personality dispositions, to which they always return following disruptive life events (Diener and Diener, 1996; Headey and Wearing, 1989; Larsen, 2000; Williams and Thompson, 1993). Research on set point theory has produced mixed evidence on the extent to which individuals are capable of fully adapting to changes. Clark et al. (2008), for instance, examined the impact of several major life events that included marriage, divorce, widowhood, and unemployment on individual life satisfaction based on the German Socio-Economic Panel. They find evidence of adaptation to all events with the exception of unemployment, which leaves a long-lasting 'scar' on individual subjective well-being. Similarly, Georgellis, Lange and Tabvuma (2012) find that employees experience a boost of job satisfaction when they get married but the effect quickly dissipates over time. By contrast, the birth of the first child has a lasting negative impact on job satisfaction among female employees, likely due to the rise of work life conflicts in the ensuing years. On balance, evidence indicates that individuals' ability to adapt to external events varies depending on the nature of the event (Easterlin, 2005; Headey, 2007; Wortman and Silver, 1987).

Job satisfaction, though generally considered a work attitude, is partly shaped by stable individual dispositions such as positive and negative affectivity (Connolly and Viswesvaran, 2000; Thoresen, Kaplan, Barsky,Warren, and de Chermont, 2003). The same logic of adaptation of life satisfaction to external events can be readily applied to analysis of job satisfaction. If individuals' adaptation to changes in external circumstances is fast and complete as suggested by set point theory, we should not expect significant differences between those who change employers within occupations and those who change employers across occupations because both groups will return to their baseline well-being over time. If 
changing jobs has a lasting impact on job satisfaction, however, the impact is likely to be greater for those who switch occupations because it represents a more significant life event. Following the pessimistic theoretical perspective which emphasizes the negative consequences of occupational change for human capital, wage growth, occupational networks and social identify, we hypothesise:

Hypothesis 3: Individuals who change employers across occupations will experience a more pronounced decrease in job satisfaction over time than those who change employers within occupation.

Finally, there are different reasons to expect a longer lasting and more negative effect of occupational change on job satisfaction. The labour economics literature emphasizes the importance of occupation-specific human capital for wage growth. Individuals who switch occupations are likely to experience a negative disruption to their wage trajectories because their pervious occupational investments tend to yield fewer economic returns in their new career (Kambourov and Manovskills, 2009; Parrado et al., 2007; Pavan, 2005). According to this perspective, switching occupations has a greater negative effect on job satisfaction than changing employers within the same occupation largely because of its negative impact on individuals' satisfaction with extrinsic aspects of the job.

Job characteristics theory and social stratification theory, on the other hand, emphasize the role of intrinsic job attributes in determining job satisfaction. Job characteristics theory suggests that individuals' job satisfaction is shaped by the intrinsic characteristics of the work itself which include skill variety, task identity, task significance, autonomy and feedback (Hackman and Oldham, 1980). As many of these core task characteristics (such as skill variety, task significance and autonomy) are closely related to an individual's skill level 
(Gallie, Felstead and Green, 2004; Goldthorpe, 2007; Green, 2013), decreased occupationspecific skills resulting from occupational change is likely to have a negative impact on one's experience of the intrinsic features inherent in the new job. Furthermore, social stratification theory emphasizes occupation as a critical force for shaping individuals' social identity and networks (Grusky and Sørensen, 1998; Weeden and Grusky, 2005). Changing occupations can disconnect individuals from their original occupational networks and bring confusion to their professional identity. According to this perspective, the greater hangover from switching occupations stems from greater disruptive changes to satisfaction with work itself. Following these two arguments, we derived our final hypothesis:

Hypothesis 4: Individuals who change employer across occupations will experience a steeper decline in satisfaction with both extrinsic and intrinsic aspects of their jobs compared to those who change employer within occupation.

3. Data and methods

\subsection{Data}

The analysis is based on the British Household Panel Survey (BHPS), a longitudinal survey funded by the Economic and Social Research Council (ESRC) and carried out by the ESRC UK Longitudinal Studies Centre with the Institute for Social and Economic Research at the University of Essex. The main objective of the survey is to advance our understanding of social and economic changes in Britain. The BHPS collected information through face-toface interviews from each adult member of sampled households, based on a stratified clustered random sample drawn from 250 Primary Sampling Units in England, Scotland and Wales representative of the British population. The first survey (wave 1) was carried out in 
1991 and consists of 10,300 individuals in 5,500 households, with a response rate of $74 \%$. Introductory letters were sent to all sampled addresses together with a leaflet outlining the purpose of the survey. Respondents were contacted within a week of dispatch and later sent a more detailed brochure with further information about the survey. The individuals who participated in the 1991 BHPS were then re-interviewed in each successive year until 2008, yielding a total of eighteen waves of datasets. If respondents left the original households, they were then followed at the new address and all adult members of the new households were also incorporated into the sample. The BHPS was extended in 1999 and 2001 to include a sample of 1,500 households for Scotland and Wales and 2,000 households for Northern Ireland. The total sample size for the BHPS is 10,000 households across the UK. As one of the longest running panel surveys in the world, the BHPS provides a wealth of information on individuals' demographic characteristics and economic and social activities.

The longitudinal nature of the data combined with large sample size enables us to identify individuals who have made various types of career transitions and follow them up for an extended period of time to track the development of their job satisfaction before and after the transition. The current analysis is focused on those reporting being an employee. Information on occupation and job satisfaction was collected through individual questionnaires which took around forty minutes to complete. If individuals had more than one job, the questions were focused on their current main job (defined as the job with most working hours). The analysis is limited to employees aged 18 to 65 , yielding an effective sample of 57,777 and 61,650 person-year observations for men and women respectively.

\subsection{Measures}

The key dependent variable is overall job satisfaction, which is measured by a single question "All things considered, how satisfied or dissatisfied are you with your present job overall?” Responses were made against a seven-point scale with ' 1 ' indicating completely 
dissatisfied and ' 7 ' indicating completely satisfied. Previous research shows that single-item measures of job satisfaction have acceptable reliability compared to composite measures derived from multiple items (Wanous, Reichers and Hudy, 1997). In addition to overall job satisfaction, individuals were also asked how satisfied they were with their pay, job security, hours of work, and work itself on the same response scale. Following the literature, we treat satisfaction with work itself as a proxy for intrinsic job satisfaction and satisfaction with pay as a proxy for extrinsic job satisfaction (Clark, 1996; Georgellis, Iossa and Tabvuma, 2011; Pouliakas and Theodossiou, 2009).

The independent variables are the different types of employer change. First, we identify overall employer change by a question that asked individuals how many distinct employers they have had since September the previous year. Those who answered two or more are taken as having changed employer in that year. The next step is to distinguish changes that involved only a change of employer from those that involved change of both employer and occupation. To this end, we followed the conventional approach in the literature (see Kambourov and Manovskills, 2002; Parrado et al., 2007) and measured occupational change by a change of occupational code at the 3-digit level of Standard Occupational Classification (SOC) across adjacent waves. We excluded within-employer occupational changes from the analysis as previous studies of honeymoon-hangover effects usually define job change as a change of employer (e.g., Boswell and Bourdreau, 2005; Boswell et al., 2009; Chadi and Hetschko, 2014) and the objective of disentangling the effects of job change on job satisfaction necessitates the focus on the experience of these individuals. Finally, we excluded the observations where a change of employer was reported but information on whether it involves a change in occupation is missing. After applying these criteria, overall employer 
change consists of two distinct and mutually exclusive categories of transitions: employer change within occupation and employer change across occupations.

A summary of different types of transitions made by individuals across the eighteen years is presented in Table 1. Over the period 1991 to 2008, a total of 12,139 employer changes were observed, of which 4,717 involved employer change within occupation and 7,422 involved employer change across occupations. The pattern is similar for men and women. Insert Table 1 about here

In order to capture temporal patterns of job satisfaction during the turnover process, we followed the approach by Clark et al. (2008) and Georgellis et al. (2012) and created lead and lag dummies around the timing of employer change for three groups of individuals: 1) those who switched employers; 2) those who switched employers within occupations, and 3) those who switched employers across occupations. The lead dummies identify up to four years prior to the change. For example, lead 3-4 years indicates four years before the transition. The lag dummies identify up to six years after the transition. Lag 0-1 year indicates the year in which the job change occurs, lag 1-2 years indicates a year after the transition, lag 2-3 years indicates two years after the transition, and so on. For individuals who change employers across occupations, the lag dummies refer to those who stayed with their employer in the same occupation after the initial transition. For example, if an individual changes his or her employer at time $\mathrm{t}$ and again at $\mathrm{t}+4$, he or she will be followed for three years after the first transition, while the second transition made at $\mathrm{t}+4$ will be considered as a new start (thus treated as t). A summary of the number of observations within each of these dummies is reported in Table 2.

Insert Table 2 about here

\subsection{Methods}


We used fixed effect models to estimate the impact of employer change within and across occupations on job satisfaction over time. A major benefit of applying fixed effect modelling to longitudinal data is that it allows us to control for time-invariant individual characteristics which can confound the effect of the independent variables. A plausible argument is that individuals who change occupations are inherently different from those who do not change occupations in ways which are not measured by the survey. Research has shown that individual personality dispositions influence both job change and levels of reported job satisfaction (Ghiselli, 1974; Judge, Heller and Mount, 2002). If unobserved individual differences (for example, negative affectivity) are correlated with both the propensity of changing occupation and reported job satisfaction, analysis based on cross-sectional data can overestimate the impact of occupational change on job satisfaction. Fixed effect models enable us to control for unobserved individual heterogeneity by focusing on within-person change over time, thus teasing out the impact of fixed individual traits which may correlate with both independent and outcome variables.

The fixed effect model is specified in the following equation:

$$
\begin{aligned}
& \mathrm{JS}_{\mathrm{it}}=\alpha_{\mathrm{i}}+\beta_{1} \text { Age }_{\mathrm{it}}+\beta_{2} \text { Martialstatus }_{\mathrm{it}}+\beta_{3} \text { Children }_{\mathrm{it}}+\beta_{4} \text { Health }_{\mathrm{it}}+\beta_{5} \text { Education }_{\mathrm{it}}++\beta_{6} \text { Tenure }_{\mathrm{it}}+ \\
& \beta_{7} \text { Contracttype }_{i t}+\beta_{8} \text { Workplacesize }_{i t}+\beta_{9} \text { Sector }_{i t}+\beta_{10} \text { Yeardummies }_{i t}+\theta_{-4} \text { Lead }_{-4, \text { it }}+\theta_{-3} \text { Lead }_{-3, \text { it }} \\
& +\theta_{-2} \operatorname{Lead}_{-2, \mathrm{it}}+\theta_{-1} \operatorname{Lead}_{-1, \mathrm{it}}+\theta_{0} \operatorname{Lag}_{0, \mathrm{it}}+\theta_{1} \operatorname{Lag}_{1, \mathrm{it}}+\theta_{2} \operatorname{Lag}_{2, \mathrm{it}}+\theta_{3} \operatorname{Lag}_{3, \mathrm{it}}+\theta_{4} \operatorname{Lag}_{4, \mathrm{it}}+\theta_{5} \operatorname{Lag}_{5, \mathrm{it}}+ \\
& \theta_{6} \operatorname{Lag}_{6, \text { it }}+\varepsilon_{\text {it }}
\end{aligned}
$$

In this equation, $\mathrm{JS}_{\mathrm{it}}$ represents job satisfaction. Following previous research, we controlled for a range of time-varying individual and workplace characteristics, which include age (and its squared terms), marital status, number of children, physical health, education, tenure, type of work contract, workplace size, and sector (Chadi and Hetschko, 2014; Clark et al., 2008, 
Georgellis and Tabvuma, 2011). In addition, we included seventeen wave dummies to control for year-specific effects (e.g. an economic recession that affects all respondents in a given year). The control variables were entered separately in the regressions on job satisfaction. The independent variables of key interest to this study are the lead and lag dummies that measure the temporal sequence of the turnover process. The coefficients of the lead dummies $\left(\theta_{-4} \operatorname{Lead}_{-4, \mathrm{it}}, \theta_{-3} \operatorname{Lead}_{-3, \mathrm{it}}, \theta_{-2} \operatorname{Lead}_{-2, \mathrm{it}}, \theta_{-1}\right.$ Lead $\left._{-1, \mathrm{it}}\right)$ capture anticipation effects and the coefficients of the lag dummies $\left(\theta_{1} \operatorname{Lag}_{1, \mathrm{it}}, \theta_{2} \operatorname{Lag}_{2, \mathrm{it}}, \theta_{3} \operatorname{Lag}_{3, \mathrm{it}}, \theta_{4} \operatorname{Lag}_{4, \mathrm{it}}, \theta_{5} \operatorname{Lag}_{5}\right.$,it, $\theta_{6} \operatorname{Lag}_{6}$,it $)$ capture adaptation effects. We first carry out analysis for overall employer change and then repeat it for employer change within occupation and employer change across occupations to explore whether the pattern of anticipation and adaptation differs for the two groups.

\section{Results}

Table 3 shows the results of the three fixed effect models estimated for overall employer change as well as within- and across-occupational employer change over a eleven-year period. In order to facilitate interpretation, we plot the coefficients of the lead and lag dummies from these models in Figure 1 and Figure 2.

\section{Insert Figure 1 and Figure 2 about here}

Figure 1 shows that individuals generally experience a honeymoon-hangover effect when they change employer, which is consistent with the findings of previous research. Comparing the pattern of employer change within and across occupations (Figure 2), however, reveals a few important differences. First, although both groups experience a dip in job satisfaction in the year preceding the transition, the effect is substantially greater in the case of employer change across occupations, which contradicts Hypothesis $1 .{ }^{1}$ Second, the analysis presented in Table 3 shows that the increase in job satisfaction that follows the transition is only significant for employer change across occupations $\left(\theta_{0}=0.14, \mathrm{p}<0.01\right)$. Although individuals 
who change employer within occupation also experience a rise of job satisfaction in the year of turnover, the effect is much smaller and statistically non-significant (Table 3). These results do not support Hypothesis 2.

Moreover, Figure 2 also shows that the pattern of adaptation differs between the two groups. In the case of employer change within occupation, job satisfaction decreases significantly in the second year after the transition and then fluctuates around the baseline level in the following years. Adaptation to employer change across occupations, however, shows a very different trajectory. After an initial surge, job satisfaction declines steadily over the subsequent six years. The slope of the decrease is steep - by the second year after the transition the honeymoon effect has entirely dissipated and by the fourth year job satisfaction has dropped below the baseline level and shows no signs of levelling off. These results provide support for Hypothesis 3.

The analysis clearly shows that employer changes within occupations entails relatively minor honeymoon and hangover effects compared to employer changes across occupations. This type of job change has little long term impact on job satisfaction as individuals fluctuate around the baseline over time. Employer change across occupations, on the other hand, entails both greater honeymoon effects and greater hangover effects. The evidence suggests that in the long run, job satisfaction steadily deteriorates rather than returning to baseline levels following a change of occupation. By the fifth year after the transition, job satisfaction has reached a level comparable to that reported two years prior to turnover and well below the level of employer change within occupation at the same stage.

To provide more insight into the differences in the pattern of development in job satisfaction following employer change within and across occupations, we estimated fixed effect regressions on satisfaction with pay and satisfaction with work itself separately (see Table 4). The coefficients of the lead and lag dummies are plotted in Figure 3. 
Insert Figure 3 about here

A clear pattern revealed by Figure 3 is that individuals who switch occupations are not worse off in terms of extrinsic job satisfaction compared to those who change employer within occupations. In fact the former even report slightly higher levels of satisfaction with pay than the latter in most years after the transition. Satisfaction with work itself, however, differs substantially between the two groups. Individuals who change employers within occupations, although seeing an initial downward trend in intrinsic job satisfaction after the transition, manage to return to their baseline by the fourth year. By contrast, those who change employer across occupations experience a continuous decline in intrinsic job satisfaction following the transition. By the sixth year after occupational change, intrinsic job satisfaction has reached the lowest point of the entire eleven-year observation period, even below the level reported the year prior to turnover. These results partially support Hypothesis 4.

\section{Discussion}

This study has provided evidence in support of the growing body of empirical evidence which shows that individuals generally experience a honeymoon-hangover effect when they change employer (Boswell and Bourdreau, 2005; Boswell et al., 2009; Chadi and Hetschko, 2014; Georgellis and Tabvuma, 2010; Georgellis and Yusuf, 2016). We have extended this stream of research by comparing the experience of those who change employer within occupation to those who simultaneously change employer and occupation. This contrast is important both theoretically and practically given the central importance of the occupational structure in determining job characteristics and in shaping individuals' experience of working life. 
Contrary to our initial expectation, we found that individuals who switched occupations experienced both a greater dip in job satisfaction prior to separation and a greater increase in job satisfaction after the transition. Although a similarly shaped curve was also found for employer change within occupation, the magnitude of the effect is much smaller and the initial rise in job satisfaction is statistically non-significant. This evidence suggests that not all job change entails a honeymoon effect. It is the combination of change in both the employing organization and job content that produces a significant boost to job satisfaction.

However, this elevated job satisfaction dissipates quickly over time. Our second major finding is that the pattern of development of job satisfaction after the transition differs between the two types of job change. Individuals who change employer within occupation experience a significant decline in job satisfaction in the second year after the transition which then levels off and fluctuates around the baseline. By contrast, those who change occupation experience a steady decline in job satisfaction which shows no sign of levelling off by the end of the observation period.

Our findings are inconsistent with previous research of occupational change which has tended to find a positive effect of occupational change on job satisfaction (e.g. Breeden, 1993; Longhi and Bryin, 2010). The inconsistency is most likely due to the fact that we have taken into account the longer-term evolution in job satisfaction after occupational change. Our analysis shows that job satisfaction rises sharply at the time of occupational change. Studies which measure the contemporaneous, or even short lag effects, of occupational change on job satisfaction are likely to have captured the honeymoon effect and extrapolated this to longer-term job satisfaction development. However, as our findings have shown, this boost to job satisfaction is nothing more than an artefact of job change and cannot be sustained over time. After a short initial honeymoon period, job satisfaction nosedives in 
subsequent years. This finding has potentially important implications for individual career planning and management.

Our analysis of job satisfaction domains provides further insights for understanding these patterns. A comparison of individuals' responses to questions about their satisfaction with pay between the two types of job changers does not support the view that 'lost' income or occupation-specific human capital (Parrado et al., 2007; Pavan, 2005) is the main driver behind the severe deterioration in job satisfaction following a change of occupation. In general, the differences between employer change within and across occupations in terms of extrinsic job satisfaction are relatively small. On the other hand, satisfaction with work itself was the main factor that differentiates the two groups. Occupational changers become increasingly disenchanted with the nature of their jobs over time and the magnitude of the negative lag coefficients shows that six years after the transition, intrinsic job satisfaction has reached the lowest point during the entire eleven-year observation period. This could reflect the consequences of change in task nature, professional identity and occupational networks on individuals' subjective well-being as job characteristics theory and social stratification theory have implied, or a rapid disillusion followed by the overly optimistic expectation that 'the grass is greener on the other side'.

These findings have several theoretical and practical implications. First, the study has enhanced our understanding of the nuances behind the honeymoon and hangover pattern uncovered by previous research, by introducing the important consideration of whether a job change involves a change of occupation or not. Dissecting the effect of overall employer change, we find that the honeymoon-hangover pattern was primarily driven by the experience of occupational changers. A change in the external workplace environment does not in itself produce a significant honeymoon effect whereas a more fundamental change of both employer and occupation creates the initial boost in job satisfaction. Second, the findings 
provide strong support for the conservative theoretical perspective which emphasizes the problematic consequences of occupational change on subjective well-being. Our analysis shows that switching occupations does not necessarily generate a lasting increase of job satisfaction by improving person-job fit. Occupational change entails a downward spiral of intrinsic job satisfaction which continues for at least six years after the transition. Third, this study has provided further evidence on set point theory. We find more support for the theory with respect only to the impact of employer change within occupation on job satisfaction. In the case of employer change across occupations, however, we find individuals are not able to fully adapt to the transition. The grass is indeed not always greener on the other side and most people seem to underestimate the challenges that they will confront when embarking on a new career.

These findings are reminiscent of past research on the impact of unemployment on subjective well-being which shows that individuals often fail to 'bounce back' to their baseline well-being following a spell of unemployment even after they are subsequently reemployed (Clark, Georgellis and Sanfey, 2001; Lucas, Clark, Georgellis and Diener, 2004). A widely observed phenomenon is that the persistent negative effect of unemployment on individual well-being goes beyond what would have expected based on a drop of income (Clark and Oswald, 1994; Winkelmann and Winkelmann, 1998) and even past unemployment has a tangible negative effect on employees' current self-esteem and wellbeing (Clark et al., 2001; Goldsmith et al., 1996). Our analysis shows that adapting to changes in job nature can also be a challenging task. If individuals who have experienced unemployment in the past are systemically more likely to find jobs in different occupations, our findings could well contribute to explaining the long-term 'scarring' effect of unemployment on subjective well-being. 
This study has a few limitations. First, although longitudinal household data has considerable advantages over cross-sectional data for tracking individual career trajectory and the dynamics of job satisfaction, the representativeness of such data can be affected by sample attrition. The decrease in the number of observations following individuals' career transition suggests that the estimated effects of the lag dummies towards the end of our observation period need to be treated with some caution. Second, there are grounds for expecting that the pattern of development in job satisfaction following occupational change are moderated by a range of situational factors. For instance, the difficulties associated with moving across occupational boundaries may vary depending on occupational characteristics, particularly with respect to occupational task complexity and skill requirements. Some occupations (e.g. law and medicine) involve significantly higher entry barriers as incumbents are often required to undertake lengthy training and pass a series of qualification tests before they are received into the occupational community. Given the higher sunk costs associated with switching out of these 'high stake' occupations, we might expect less frequent turnover in these occupations and greater psychological aftermath when individuals change the direction of their career. In contrast, the impact of switching occupations on job satisfaction may be less pronounced for employees in occupations which requires little investment in occupation-specific human capital. Future research could investigate how occupational properties moderate the impact of occupational change on job satisfaction.

Third, this study has focused on individuals who change employer. This focus was chosen because previous studies of honeymoon-hangover effects usually define job change as a change of employer and the objective of dissecting the effects of job change on job satisfaction necessitates the focus on this sample. However, occupational change within employer also represents an interesting type of career move which merits research attention. Internal transfers to different functional departments can be accompanied by different 
patterns of anticipation and adaptation from between-employer occupational change. For instance, a less pronounced honeymoon effect may be observed because individuals are likely to have more realistic understanding of their current employing organization which can suppress the initial surge of positive affect upon job entry. Similarly, the hangover effect may be cushioned by factors such as better prior knowledge of job tasks in other departments before the transition and the continued social support network that individual can access in the workplace after the transition. As a significant proportion of occupational change occur without a change of employer, the dynamics of within-firm job change calls for future research.

Finally, it is possible that impact of occupational change on job satisfaction revealed by this study is influenced by the contextual factors which characterised the UK labour market during the 1990s and 2000s. Research has shown that the fast spread of computerised technologies during the period was accompanied by an extensive up-skilling of the labour force and rising work intensification (Green, 2006; Green and McIntosh, 2001; Green and Gallie, 2002). Increasing global market competition and changes in public policies and labour market institutions (e.g., the decline of trade union influence) was associated with a significance rise in perceived job insecurity (Burchell, Ladipo and Wilkinson, 2002). Several studies have found that there has been a significant decline in employee subjective well-being in the UK over the last two decades (Clark, 2005; Green et al., 2014). These contextual factors imply that it may have become increasingly difficult for individuals to move up the occupational ladder and land high quality jobs when they make a career transition. As individuals' career choices often reflect the opportunity structure and constraints that characterised the labour market, the extent to which these findings can be replicated in other countries characterised by different economic and institutional environment is likely to remain a fertile ground for future research. 


\section{Conclusion}

This study was largely inspired by Boswell and Boudreau's (2005) influential study of the relationship between job satisfaction and job change to provide further within-individual longitudinal evidence on the temporal sequence of job satisfaction during the turnover process. Extending Boswell and Boudreau's study which focused on a predominantly male and white sample within a single occupation (high-level managers), we have analysed a larger and more representative sample of British employees and included a longer set of lead and lag time dummies to track the evolution of job satisfaction across a eleven year period. We provide further insight into the pattern by comparing the experience of those who change employer within and across occupations. Our analysis reveals the honeymoon effect was primarily driven by the experience of those who change employer across occupations. Patterns of post-transition adaptation also differs between the two categories of job changers. While individuals who change employer within occupation return to their baseline well-being over time, those who change employer across occupations experience a steep decline of intrinsic job satisfaction which continues for at least six years after the transition. Overall, our study demonstrates occupational considerations are crucial in understanding the impact of job changes on job satisfaction.

\section{References}

Acemoglu, D. (2002). Technical change, inequality, and the labor market. Journal of Economic Literature, 40, 1, 7-72.

Ashforth, B. E. (2001). Role transitions in organizational life: An identity based perspective. Mahwah, NJ: Erlbaum. 
Autor, D. \& Dorn, D. (2013). The growth of low skill service jobs and the polarization of the US labor market. American Economic Review, 103, 5, 1553-1597.

Becker, G. (1993). Human Capital, 3rd ed. Chicago: University of Chicago Press.

Blauner, R. (1960). Work satisfaction and industrial trends in modern society. University of California.

Broom, L. \& Smith, J.H. (1963). Bridging occupations. The British journal of sociology, 14, $4,321-334$.

Borzaga, C. \& Tortia, E. (2006). Worker motivations, job satisfaction, and loyalty in public and nonprofit social services. Nonprofit and Voluntary Sector Quarterly, 35, 2, 225-48.

Boswell, W.R., Boudreau, J.W. \& Tichy, J. (2005). The relationship between employee job change and job satisfaction: the honeymoon-hangover effect. .Journal of Applied Psychology, 90, 5, 882-892.

Boswell, W.R., Shipp, A.J., Payne, S.C. \& Culbertson, S.S. (2009). Changes in newcomer job satisfaction over time: examining the pattern of honeymoons and hangovers. Journal of Applied Psychology, 94, 4, 844.

Breeden, S.A. (1993). Job and occupational change as a function of occupational correspondence and job satisfaction. Journal of Vocational Behavior, 43, 1, 30-45.

Brickman, P. \& Campbell, D.T. (1971). Hedonic relativism and planning the good society. Adaptation-level theory, 287-305.

Brickman, P., Coates, D. \& Janoff-Bulman, R. (1978). Lottery winners and accident victims: Is happiness relative? Journal of personality and social psychology, 36, 8, 917.

Burchell, B., Ladipo, D., \& Wilkinson, F. (Eds.). (2005). Job insecurity and work intensification. Routledge. 
Chadi, A. and Hetschko, C. (2014). The magic of the new: how job changes affect job satisfaction (No. 05/2014). IAAEU Discussion Paper Series in Economics.

Chatman, J. A. (1991). Matching people and organizations: Selection and socialization in public accounting firms. Administrative Science Quarterly, 36, 459-484.

Clark, A.E. (1996) Job satisfaction in Britain. British Journal of Industrial Relations, 34, 2,189-217.

Clark, A.E., Diener, E., Georgellis, Y. \& Lucas, R.E. (2008). Lags and leads in life satisfaction: a test of the baseline hypothesis. The Economic Journal, 118, 529, F222F243.

Clark, A. E., Georgellis, Y. \& Sanfey, P. (2001). Scarring: The psychological impact of past unemployment,. Economica, 68, 270, 221-241.

Clark, A. E., Georgellis, Y. \& Sanfey, P. (2012). Job satisfaction, wage changes, and quits: Evidence from Germany. Research in Labor Economics, 35, 1, 499-525.

Clark, A.E. \& Oswald, A.J. (1994). Unhappiness and unemployment. The Economic Journal, 104, 424, 648-659.

Connolly, J.J. \& Viswesvaran, C. (2000). The role of affectivity in job satisfaction: A metaanalysis. Personality and individual differences, 29, 2, 265-281.

Costa, P.T. \& McCrae, R.R. (1980). Influence of extraversion and neuroticism on subjective well-being: happy and unhappy people. Journal of personality and social psychology, 38, 4, 668 .

Davis, K. \& Moore, W.E. (1945). Some principles of stratification. American Sociological Review, 10, 2, 242-249.

Diener, E. \& Diener, C. (1996). Most people are happy. Psychological Science, 7, 3,181-185. 
Edwards, J.R. (1991). Person-job fit: A conceptual integration, literature review, and methodological critique. John Wiley \& Sons.

Easterlin, R.A. (2005). A puzzle for adaptive theory. Journal of Economic Behavior \& Organization, 56, 4, 513-521.

Fichman, M. \& Levinthal, D.A. (1991). Honeymoons and the liability of adolescence: A new perspective on duration dependence in social and organizational relationships. Academy of Management Review, 16, 2, 442-468.

Gallie, D., Felstead, A. and Green, F. (2004). Changing patterns of task discretion in Britain. Work, Employment \& Society, 18, 2, 243-266.

Gallie, D., Felstead, A. \& Green, F. (2012). Job preferences and the intrinsic quality of work: the changing attitudes of British employees 1992-2006. Work, Employment \& Society, 26, 5, 806-821.

Georgellis, Y., Iossa, E., \& Tabvuma, V. (2011). Crowding out intrinsic motivation in the public sector. Journal of Public Administration Research and Theory, 21, 3, 473-493.

Georgellis, Y., Lange, T. \& Tabvuma, V. (2012). The impact of life events on job satisfaction. Journal of Vocational Behavior. 80, 2, 464-473.

Georgellis, Y., \& Tabvuma, V. (2010). Does public service motivation adapt? Inc Kyklos, 63, 2, 176-191.

Georgellis, Y., \& Yusuf, A. (2016). Is becoming self-employed a panacea for job satisfaction? Longitudinal evidence from work to self-employment transitions. Journal of Small Business Management, Forthcoming.

Ghiselli, E.E. (1974). Some perspectives for industrial psychology. American Psychologist, 29, 2, 80. 
Goldsmith, A.H., Veum, J.R. \& Darity, W. (1996). The psychological impact of unemployment and joblessness. The journal of socio-economics, 25, 3, 333-358.

Goldthorpe, J.H. (2007). On sociology (Vol. 2). Stanford University Press.

Green, F. (2006). Demanding work. The paradox of job quality in the affluent economy. Princeton: Princeton University Press.

Green, F. (2013). Skills and skilled work: An economic and social analysis. Oxford: Oxford University Press.

Green, F. \& McIntosh, S. (2001). The intensification of work in Europe. Labour Economics, 8, 2, 291-308.

Grusky, D.B., \& Sorensen, J.B. (1998). Can class analysis be salvaged? American Journal of Sociology, 103, 5, 1187-234.

Hackman, J.R. \& Oldham, G.R. (1980). Work redesign. Reading, Mass: Addison-Wesley.

Hagedorn, M., Kambourov, G. \& Manovskii, I. (2005). Worker mobility in the United States and Germany: a primer. Mimeo: University of Pennsylvania.

Headey, B. (2007). The set-point theory of well-being needs replacing-on the brink of a scientific revolution? SOEP Paper, (55).

Headey, B. \& Wearing, A. (1989). Personality, life events, and subjective well-being: toward a dynamic equilibrium model. Journal of Personality and Social psychology, 57, 4, 731.

Heady, B., \& Wearing, A. (1992). Understanding happiness: A theory of subjective wellbeing. Melbourne, Australia: Longman Chesire.

Huang, X., \& Van de Vliert, E. (2003). Where intrinsic job satisfaction fails to work: national moderators of intrinsic motivation. Journal of Organizational Behavior, 24, 2, 159-79. 
Jencks, C. M. (1972) Inequality: A reassessment of the effect of family and schooling in America. New York: Basic Books.

Ilgen, D.R. (1971). Satisfaction with performance as a function of the initial level of expected performance and the deviation from expectations. Organizational Behavior and Human Performance, 6, 3, 345-361.

Judge, T. A., Heller, D., \& Mount, M. K. (2002). Five-factor model of personality and job satisfaction: A meta-analysis. Journal of Applied Psychology, 87, 530-541.

Kahn. R. L. (1972). The meaning of work: Interpretations and proposals for measurement. In A. Capwell, \& Converse, P. E. (Eds.) The human meaning of social change. New York: Russell Sage Foundation.

Kahneman, D. (1999). Objective happiness. In D. Kahneman, E, Diener. \& N, Schwarz. (Eds.), Well-being: The foundation of hedonic psychology (pp. 3-25). New York: Russell Sages Foundation.

Kalleberg, A.L. (2011). Good jobs, bad jobs. New York: Russell Sage Foundation.

Kalleberg, A. L. \& Griffin, L.J. (1978). Positional sources of inequality in job satisfaction. Sociology of Work and Occupations, 5, 4, 371-401.

Kambourov, G. \& Manovskii, I. (2009). Occupational specificity of human capital. International Economic Review, 50, 1, 63-115.

Kristof-Brown, A. \& Guay, R.P. (2011). Person-environment fit. In Zedeck, Sheldon (Eds.), APA handbook of industrial and organizational psychology, Vol 3: Maintaining, expanding, and contracting the organization. Washington, DC. US: American Psychological Association. 
Kwon, I. \& Milgrom, E.M. (2004). Boundaries of internal labor markets: the relative importance of firms and occupations. mimeo, Stanford University Graduate School of Business.

Larsen, R. J. (2000). Toward a science of mood regulation. Psychological Inquiry, 11, 129141.

Lauver, K.J. \& Kristof-Brown, A. (2001). Distinguishing between employees' perceptions of person-job and person-organization fit. Journal of Vocational Behavior, 59, 3, 454470.

Lawler, E. E., Kuleck, W. J., Rhode, J. G., \& Sorensen, J. E. (1975). Job choice and post decision dissonance. Organizational Behavior \& Human Decision Processes, 13, 133145.

Leblibici, H., \& Salancik, G. R. (1982). Stability in interorganizational exchanges: Rulemaking processes in the Chicago Board of Trade. Administrative Science Quarterly, 27, 227-242.

Lemieux, T. (2006). 'Increasing residual wage inequality: composition effects, noisy data, or rising demand for skill’? American Economic Review, 96(3): 461-498.

Lévy-Garboua, L., Montmarquette, C. and Simonnet, V., 2007. Job satisfaction and quits. Labour Economics, 14(2), 251-268.

Longhi, S. \& Brynin, M. (2010). Occupational change in Britain and Germany. Labour Economics, 17, 4, 655-666.

Louis, M. E. (1980). Surprise and sense making: What new comers experience in entering unfamiliar organizational settings. Administrative Science Quarterly, 25, 226-251.

Lucas, Clark, Georgellis and Ed Diener, 2004. Unemployment Alters the Set Point for Life Satisfaction, Psychological Science, 15 (1): 8-13. 
Lykken, D. \& Tellegen, A. (1996). Happiness is a stochastic phenomenon. Psychological Science, 7, 3, 186-189.

Meglino, B. M., and DeNisi, A. S. (1987). Realistic job previews: Some thoughts on their more effective use in managing the flow of human resources. Human Resource Planning, 10, 157-167.

Mouw, T. \& Kalleberg, A.L. (2010). Occupations and the structure of wage inequality in the United States, 1980s to 2000s. American Sociological Review, 75, 3, 402-431.

Muffels, R.J. (Eds.) (2014). Flexibility and employment security in Europe. Edward Elgar Publishing.

Parrado, E., Caner, A. \& Wolff, E.N. (2007). Occupational and industrial mobility in the United States. Labour Economics, 14, 3, 435-455.

Pavan, R. (2005). Career choice and wage growth. Working paper, University of Rochester.

Pouliakas, Konstantinos and Ioannis Theodossiou (2009). Confronting objections to performance pay: A study of the impact of individual and gain-sharing incentives on the job satisfaction of British employees. Scottish Journal of Political Economy, 56, 5, $662-684$.

Rose, M. (2003). Good deal, bad deal? Job satisfaction in occupations. Work, Employment \& Society, 17, 3, 503-530.

Slocum, W. L. (1966). Occupational careers. Chicago: Aldine.

Stewart, A., Prandy, K. \& Blackburn, R.M. (1980). Social stratification and occupations. London: Macmillan. 
Tabvuma, V., Georgellis, Y., \& Lange, T. (2015). Orientation training and job satisfaction: A sector and gender analysis. Human Resource Management, 54, 2, 303-321.

Thoresen, C. J., Kaplan, S. A., Barsky, A. P., Warren, C. R., \& de Chermont, K. (2003). The affective underpinnings of job perceptions and attitudes: A meta-analytic review and integration. Psychological Bulletin, 129, 914-945.

Van Maanen, J. (1975). Police socialization: A longitudinal examination of job attitudes in an urban police department. Administrative Science Quarterly, 207-228.

Vroom, V. H., \& Deci, E. L. (1971). The stability of post-decision dissonance: A follow-up study of the job attitudes of business school graduates. Organizational Behavior and Human Performance, 6, 36-49.

Wanous, John P.; Reichers, Arnon E.; Hudy, Michael J. (1997). Overall job satisfaction: How good are single-item measures? Journal of Applied Psychology, 82, 2, 247-252.

Ward, L.B. \& Athos, A.G. (1972). Student expectations of corporate life: Implications for management recruiting.

Weeden, K.A. (2002). Why do some occupations pay more than others? Social closure and earnings inequality in the United States. American Journal of Sociology 108, 1, 55-101.

Weeden, K.A. and Grusky, D.B. (2005). The case for a new class map .American Journal of Sociology, 111, 1, 141-212.

Weeden, K.A. \& Grusky, D.B. (2012). The three worlds of inequality. American Journal of Sociology, 117, 6, 1723-1785.

Williams, D. E., \& Thompson, J. K. (1993). Biology and behavior: A set-point hypothesis of psychological functioning. Behavior Modification, 17, 43-57. 
Williams M. T. (2013). Occupations and British wage inequality, 1970s-2000s. European Sociological Review, 29, 4, 841-857.

Winkelmann, L. \& Winkelmann, R (1998). Why are the unemployed so unhappy? Evidence from panel data. Economica, 65, 257, 1-15

Wortman, C.B. \& Silver, R.C. (1987). Coping with irrevocable loss. In American Psychological Association Convention, Aug, 1986, Washington, DC, US; This chapter is based upon one of the 1986 Master Lectures that were presented at the aforementioned convention. American Psychological Association.

Zangelidis, A. (2008). Occupational and industry specificity of human capital in the British labour market. Scottish Journal of Political Economy, 55, 4, 420-443.

Zou, M. (2015). Gender, work orientations and job satisfaction. Work, Employment and Society, 29, 1, 3-22. 


\section{TABLES}

Table 1 Number of overall employer change, employer change within occupation and employer change across occupations 1991-2008

\begin{tabular}{llll}
\hline & Men & Women & All \\
\hline Overall employer change & 6,042 & 6,097 & 12,139 \\
Employer change within occupation & 2,366 & 2,351 & 4,717 \\
Employer change across occupations & 3,676 & 3,746 & 7,422 \\
\hline
\end{tabular}

Table 2 Number of observations of leads and lags

\begin{tabular}{llll}
\hline & $\begin{array}{l}\text { Overall employer } \\
\text { change }\end{array}$ & $\begin{array}{l}\text { Employer change } \\
\text { within occupation }\end{array}$ & $\begin{array}{l}\text { Employer change } \\
\text { across occupations }\end{array}$ \\
\hline Leads & & & \\
3-4 years & 6,720 & 2,697 & 4,023 \\
2-3 years & 7,997 & 3,262 & 4,735 \\
1-2 years & 9,489 & 3,887 & 5,602 \\
Within the next year & 11,678 & 4,806 & 6,872 \\
& & & \\
Lags & 12,139 & 4,717 & 7,422 \\
0-1 year & 4,974 & 2,361 & 2,613 \\
1-2 years & 2,633 & 1,353 & 1,280 \\
2-3 years & 1,494 & 815 & 679 \\
3-4 years & 908 & 505 & 403 \\
4-5 years & 583 & 324 & 259 \\
5-6 years & 358 & 208 & 150 \\
6-7 years & & & \\
\hline
\end{tabular}

Note: Leads measure the number of years before the transition and lags measure the number of years after the transition. For instance, lag 0-1 year indicates the year in which the transition occurs, lag 1-2 years indicates a year after the transition, lag 2-3 years indicates two years after the transition, and etc. 
Table 3 Fixed effect regressions on job satisfaction

\begin{tabular}{|c|c|c|c|}
\hline & $\begin{array}{l}\text { Overall employer } \\
\text { change }\end{array}$ & $\begin{array}{l}\text { Employer change } \\
\text { within occupations }\end{array}$ & $\begin{array}{l}\text { Employer change } \\
\text { across occupations }\end{array}$ \\
\hline \multicolumn{4}{|l|}{ Leads } \\
\hline $3-4$ years & $-0.05 * * *$ & $-0.05^{*}$ & $-0.06 * * *$ \\
\hline $2-3$ years & $-0.08 * * *$ & $-0.08 * * *$ & $-0.09 * * *$ \\
\hline 1-2 years & $-0.16 * * *$ & $-0.14 * * *$ & $-0.17 * * *$ \\
\hline Within the next year & $-0.51 * * *$ & $-0.33 * * *$ & $-0.58 * * *$ \\
\hline \multicolumn{4}{|l|}{ Lags } \\
\hline $0-1$ year & $0.11 * * *$ & -0.01 & $0.14 * * *$ \\
\hline $1-2$ years & -0.04 & $-0.16^{* * *}$ & 0.01 \\
\hline $2-3$ years & $-0.08 * *$ & $-0.18 * * *$ & -0.06 \\
\hline $3-4$ years & $-0.14 * * *$ & $-0.20 * * *$ & $-0.17 * * *$ \\
\hline 4-5 years & $-0.15 * * *$ & $-0.16^{* *}$ & $-0.21 * * *$ \\
\hline $5-6$ years & $-0.12 *$ & -0.03 & $-0.27 * * *$ \\
\hline $6-7$ years & $-0.27 * * *$ & $-0.19 *$ & $-0.44 * * *$ \\
\hline \multicolumn{4}{|l|}{ Controls } \\
\hline Age & 0.00 & 0.00 & 0.00 \\
\hline Age squared & $0.00 * * *$ & $0.00 * *$ & $0.00 * *$ \\
\hline Tenure & $-0.02 * * *$ & $-0.03 * * *$ & $-0.02 * * *$ \\
\hline Workplace size 25-499 & $-0.06 * * *$ & $-0.05 * * *$ & $-0.05 * * *$ \\
\hline Workplace size $500+$ & $-0.05 * *$ & $-0.04 *$ & $-0.04 *$ \\
\hline Private sector & $-0.19 * * *$ & $-0.22 * * *$ & $-0.20 * * *$ \\
\hline Married & -0.02 & -0.02 & -0.03 \\
\hline Number of children & $0.04 * * *$ & $0.04 * * *$ & $0.04 * * *$ \\
\hline Education (CSE) & $-0.37 * *$ & $-0.38 * *$ & $-0.37 * *$ \\
\hline Education (O level) & $-0.26 * * *$ & $-0.27 * * *$ & $-0.27 * * *$ \\
\hline Education (A level) & -0.15 & $-0.15^{*}$ & $-0.15^{*}$ \\
\hline \multicolumn{4}{|l|}{ Education (HND, HNC, } \\
\hline Teaching) & $-0.21 * *$ & $-0.26 * *$ & $-0.23 * *$ \\
\hline Education (First degree) & $-0.21 * *$ & $-0.29 * * *$ & $-0.24 * *$ \\
\hline Education (Higher degree) & -0.05 & -0.12 & -0.09 \\
\hline Full-time & $-0.16^{* * *}$ & $-0.16^{* * *}$ & $-0.17 * * *$ \\
\hline Logged gross monthly pay & $0.10 * * *$ & $0.11 * * *$ & $0.10 * * *$ \\
\hline No health problems & $0.07 * * *$ & $0.07 * * *$ & $0.07 * * *$ \\
\hline
\end{tabular}

Notes: the regressions control for wave dummies. Reference for the categorical variables: workplace size 1-24, public sector, single, no qualifications, part-time work, reported health problems. $* * * \mathrm{p}<0.01, * * \mathrm{p}<0.05, * \mathrm{p}<0.1$. 
Table 4 Effect of employer change within and across occupations on satisfaction with pay and satisfaction with work itself

\begin{tabular}{|c|c|c|c|c|}
\hline & \multicolumn{2}{|c|}{ Satisfaction with pay } & \multicolumn{2}{|c|}{ Satisfaction with work itself } \\
\hline & $\begin{array}{l}\text { within } \\
\text { occupation }\end{array}$ & $\begin{array}{l}\text { across } \\
\text { occupations }\end{array}$ & $\begin{array}{l}\text { within } \\
\text { occupation }\end{array}$ & $\begin{array}{l}\text { across } \\
\text { occupations }\end{array}$ \\
\hline \multicolumn{5}{|l|}{ Leads } \\
\hline $3-4$ years & $-0.05^{*}$ & -0.04 & -0.04 & $-0.04 *$ \\
\hline 2-3 years & -0.04 & $-0.10 * * *$ & $-0.06 * *$ & $-0.06 * *$ \\
\hline $1-2$ years & $-0.14 * * *$ & $-0.15 * * *$ & $-0.08 * * *$ & $-0.13 * * *$ \\
\hline Within the next year & $-0.20 * * *$ & $-0.33 * * *$ & $-0.13 * * *$ & $-0.37 * * *$ \\
\hline \multicolumn{5}{|l|}{ Lags } \\
\hline $0-1$ years & $0.10 * * *$ & $0.13 * * *$ & 0.01 & $0.16 * * *$ \\
\hline $1-2$ years & $-0.12 * * *$ & -0.06 & $-0.09 * *$ & $0.06^{* *}$ \\
\hline 2-3 years & $-0.15 * * *$ & -0.03 & $-0.15 * * *$ & -0.06 \\
\hline $3-4$ years & -0.07 & -0.08 & $-0.19 * * *$ & $-0.14 * *$ \\
\hline 4-5 years & $-0.22 * *$ & -0.08 & $-0.16^{*}$ & $-0.17 * *$ \\
\hline $5-6$ years & -0.09 & 0.02 & -0.10 & $-0.25 * *$ \\
\hline $6-7$ years & -0.07 & -0.17 & 0.04 & $-0.45 * * *$ \\
\hline \multicolumn{5}{|l|}{ Controls } \\
\hline Age & -0.01 & -0.01 & $0.03 *$ & $0.03 *$ \\
\hline Age squared & $0.00 * * *$ & $0.00 * * *$ & $-0.00 * * *$ & $-0.00 * * *$ \\
\hline Tenure & $-0.02 * * *$ & $-0.02 * * *$ & $-0.02 * * *$ & $-0.02 * * *$ \\
\hline Workplace size $25-499$ & 0.00 & 0.00 & $-0.11 * * *$ & $-0.11 * * *$ \\
\hline Workplace size $500+$ & $0.04 *$ & 0.04 & $-0.12 * * *$ & $-0.13 * * *$ \\
\hline Private sector & $-0.11 * * *$ & $-0.09 * * *$ & $-0.23 * * *$ & $-0.21 * * *$ \\
\hline Married & 0.01 & 0.00 & -0.02 & -0.02 \\
\hline Number of children & $0.05 * * *$ & $0.05 * * *$ & $0.02 * *$ & $0.02 * *$ \\
\hline Education (CSE) & -0.03 & -0.02 & $-0.36 * *$ & $-0.35 * *$ \\
\hline Education (O level) & -0.03 & -0.03 & $-0.22 * *$ & $-0.22 * *$ \\
\hline Education (A level) & 0.04 & 0.04 & -0.08 & -0.07 \\
\hline $\begin{array}{l}\text { Education (HND, HNC, } \\
\text { Teaching) }\end{array}$ & -0.12 & -0.09 & -0.08 & -0.06 \\
\hline Education (First degree) & $-0.39 * * *$ & $-0.35 * * *$ & -0.12 & -0.08 \\
\hline $\begin{array}{l}\text { Education (Higher } \\
\text { degree) }\end{array}$ & $-0.45 * * *$ & $-0.43 * * *$ & 0.07 & 0.10 \\
\hline Full-time & $-0.54 * * *$ & $-0.55 * * *$ & $-0.09 * * *$ & $-0.10 * * *$ \\
\hline $\begin{array}{l}\text { Logged gross monthly } \\
\text { pay }\end{array}$ & $0.58 * * *$ & $0.58 * * *$ & $0.10 * * *$ & $0.09 * * *$ \\
\hline No health problems & $0.04 * *$ & $0.03 * *$ & $0.07 * * *$ & $0.07 * * *$ \\
\hline
\end{tabular}

Notes: the regressions control for wave dummies. Reference for the categorical variables: workplace size 1-24, public sector, single, no qualifications, part-time work, reported health problems. $* * * \mathrm{p}<0.01, * * \mathrm{p}<0.05, * \mathrm{p}<0.1$. 


\section{FIGURES}

Figure 1 Effect of overall employer change on job satisfaction

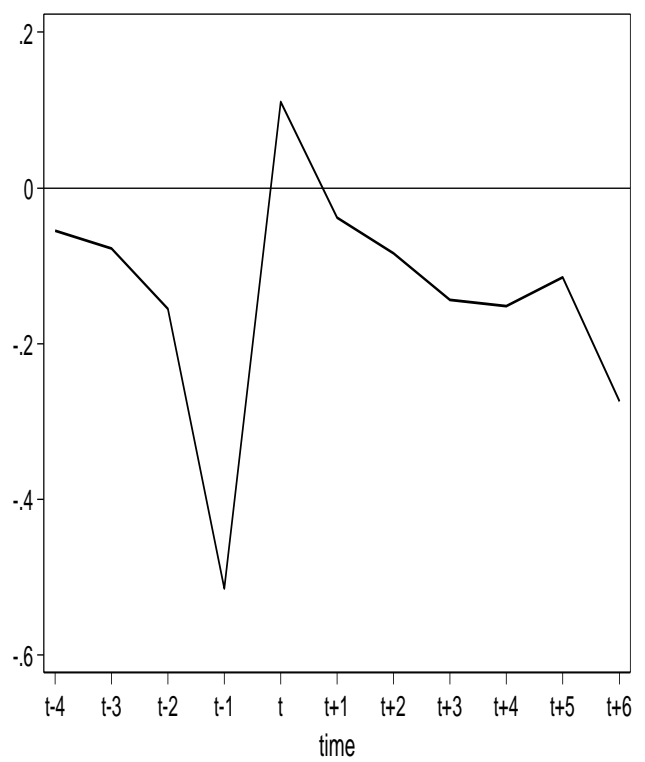

Figure 2 Effect of employer change within and across occupations on job satisfaction

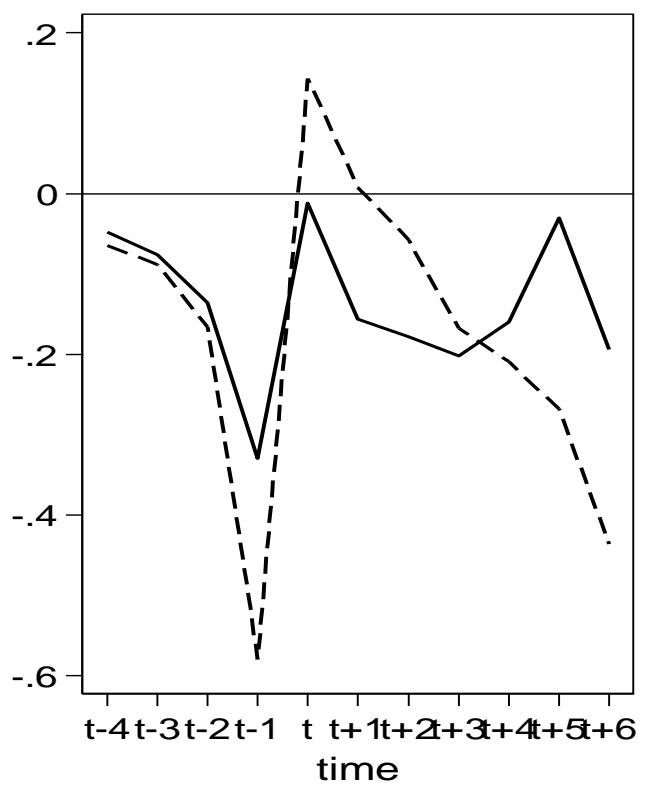


Figure 3 Effect of employer change within and across occupations on domain job satisfaction

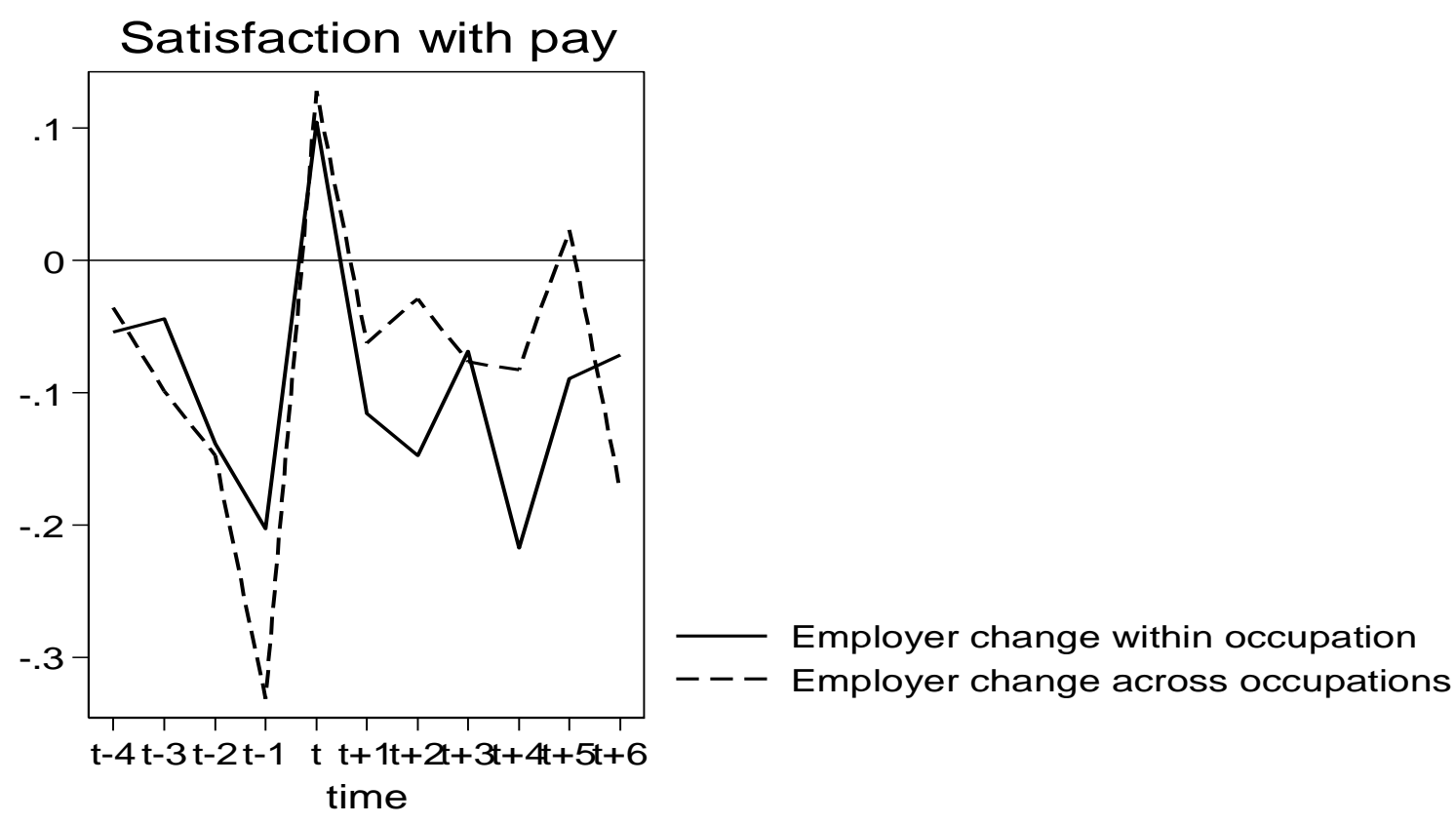

\section{Satisfaction with work itself}

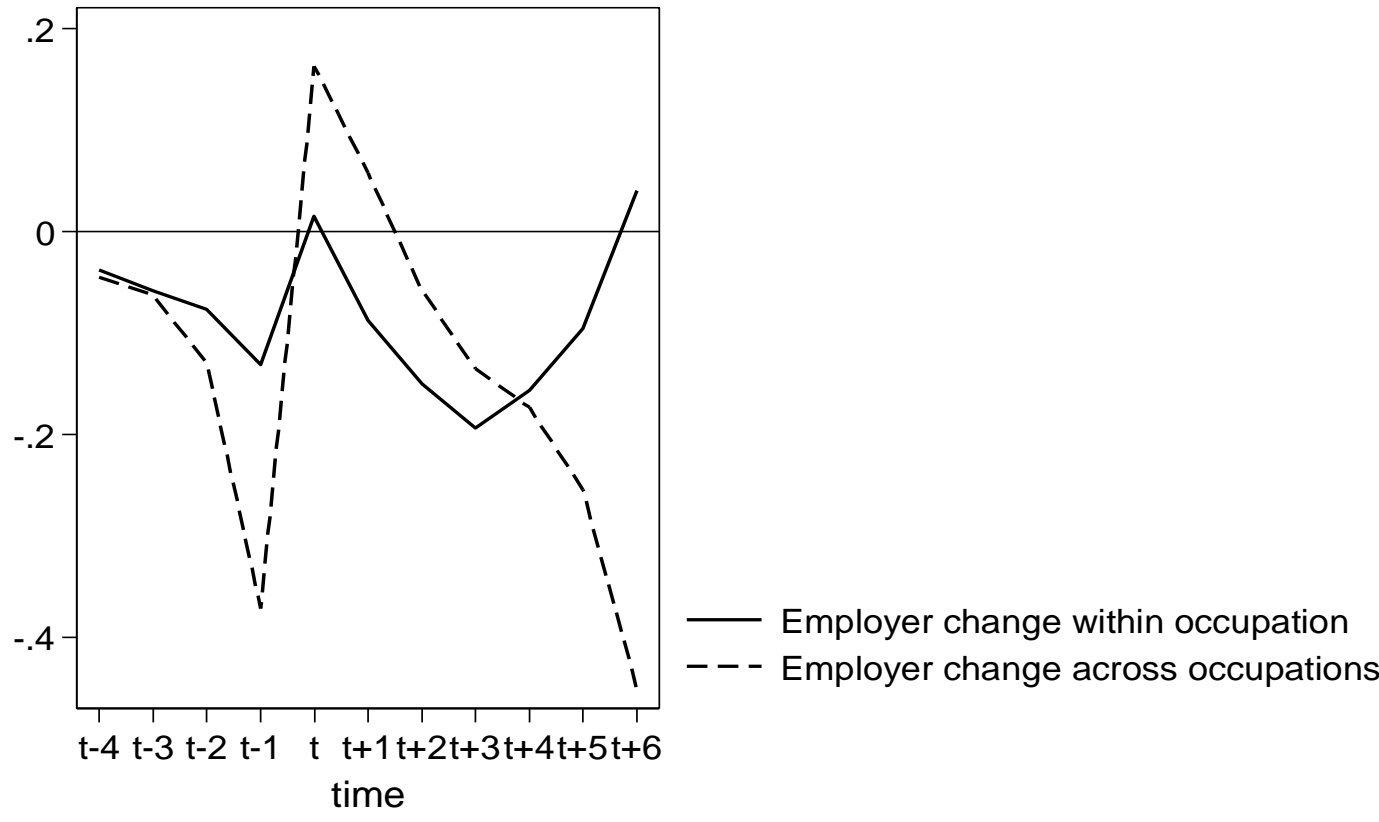


1. A fixed effect regression that includes the interactive effects of overall employer change and occupational change shows that the difference between employer change within and across occupation coefficients are statistically significant $(\mathrm{p}<0.01)$. 